\title{
Bacteroides intestinalis sp. nov., isolated from human faeces
}

\author{
Mohammad Abdul Bakir, ${ }^{1}$ Maki Kitahara, ${ }^{1}$ Mitsuo Sakamoto, ${ }^{1}$ \\ Mitsuharu Matsumoto ${ }^{2}$ and Yoshimi Benno ${ }^{1}$ \\ ${ }^{1}$ Microbe Division/Japan Collection of Microorganisms, RIKEN BioResource Center, Wako, \\ Saitama 351-0198, Japan \\ ${ }^{2}$ Laboratory of Dairy Science and Technology, Kyodo Milk Industry Co. Ltd, Hinode, Tokyo \\ 190-0182, Japan
}

Correspondence

Mohammad Abdul Bakir

bakir@jcm.riken.jp
Polyamines such as putrescine, spermidine and spermine are organic cations required for animal cell growth and differentiation and in various steps of DNA, RNA and protein synthesis. Both prokaryotic and eukaryotic cells synthesize polyamines (Capano et al., 1998; McCormack et al., 1998). The polyamines found in the intestinal lumen originate from endogenous and exogenous sources. Polyamines derived from food are absorbed in the small intestine and thus are unable to fulfil the high metabolic demand for polyamines of the mucosal tissue in the large bowel (Bardocz et al., 1993). Bacteria present in the human gut serve as a possible source of polyamines (Satink et al., 1989). Members of the genera Bacteroides and Fusobacterium and anaerobic cocci are able to synthesize large amounts of putrescine and spermidine in rats (Noack et al., 1998). The use of polyamine-deficient media facilitates the isolation of polyamine-producing bacteria (Noack et al., 2000). During an investigation of micro-organisms grown on polyaminedeficient medium, we isolated the strains reported here.

Published online ahead of print on 9 September 2005 as DOI 10.1099/ijs.0.63914-0.

The GenBank/EMBL/DDBJ accession number for the 16S rRNA gene sequence of strain $341^{\top}$ is $A B 214328$.

Biochemical characteristics determined using the API systems, cellular fatty compositions, DNA $\mathrm{G}+\mathrm{C}$ contents and levels of DNA-DNA hybridization among the novel strains and related Bacteroides species are available as supplementary tables in IJSEM Online.
Five bacterial strains (strains 276, 281, 341 ${ }^{\mathrm{T}}, 342$ and 344 ) were isolated from the faeces of healthy Japanese adults (strains 276 and 281 were from a 40 -year-old male and the others from a 32-year-old female). The polyamine-deficient medium of Noack et al. (1998), with minor modification, and a standard dilution plate method were used for isolation. The composition of the medium was as follows (mmol l${ }^{-1}$ unless indicated): MOPS (40), Tricine (4), $\mathrm{K}_{2} \mathrm{HPO}_{4}(1 \cdot 3), \mathrm{NaHCO}_{3}(119), \mathrm{NaCl}(85 \cdot 5), \mathrm{NH}_{4} \mathrm{Cl}(9 \cdot 5)$, glucose $(27 \cdot 3)$, L-amino acid mixture [alanine $(3 \cdot 6)$, arginine $(1 \cdot 6)$, asparagine $(1 \cdot 9)$, aspartic acid $(1 \cdot 5)$, cystine $(0 \cdot 12)$, cysteine $(3 \cdot 3)$, glutamic acid $(2 \cdot 7)$, glutamine $(3 \cdot 4)$, glycine $(8 \cdot 5)$, histidine $(0 \cdot 6)$, isoleucine $(1 \cdot 7)$, leucine $(2 \cdot 8)$, lysine $(12 \cdot 3)$, methionine $(0 \cdot 7)$, ornithine $(2 \cdot 0)$, phenylalanine $(1 \cdot 3)$, proline $(4 \cdot 9)$, serine $(2 \cdot 3)$, threonine $(1 \cdot 7)$, tryptophan $(0 \cdot 2)$, tyrosine $(0 \cdot 7)$ and valine $(2 \cdot 4)]$, purines and pyrimidines [adenine, guanine, cytosine and uracil $(0 \cdot 2$ each)], sodium succinate $(9 \cdot 0)$, haemin $(0 \cdot 015)$, vitamins $\left[\left(\mu \mathrm{mol} \mathrm{l}^{-1}\right)\right.$ : $p$-aminobenzoic acid $(0 \cdot 4)$, folic acid $(0 \cdot 05)$, biotin $(0 \cdot 08)$, nicotinic acid $(0 \cdot 3)$, calcium pantothenate $(0 \cdot 1)$, thiamine hydrochloride $(0 \cdot 15)$, pyridoxine hydrochloride $(0 \cdot 49)$ and menadione $(1 \cdot 1)]$, mineral mixture $\left[\left(\mu \mathrm{mol} \mathrm{l} \mathrm{l}^{-1}\right): \mathrm{MgSO}_{4} \cdot 7 \mathrm{H}_{2} \mathrm{O}(121 \cdot 7), \mathrm{MnSO}_{4} \cdot 4 \mathrm{H}_{2} \mathrm{O}(22 \cdot 4)\right.$, $\mathrm{CaCl}_{2} \cdot 2 \mathrm{H}_{2} \mathrm{O}(6 \cdot 8), \mathrm{ZnSO}_{4} \cdot 7 \mathrm{H}_{2} \mathrm{O}(3 \cdot 5), \mathrm{CoCl}_{2} \cdot 6 \mathrm{H}_{2} \mathrm{O}(4 \cdot 2)$, $\mathrm{Fe}(\mathrm{II}) \mathrm{SO}_{4} \cdot 7 \mathrm{H}_{2} \mathrm{O} \quad(3 \cdot 6), \mathrm{H}_{3} \mathrm{BO}_{3} \quad(1 \cdot 6), \quad \mathrm{Na}_{2} \mathrm{MoO}_{4} \cdot 2 \mathrm{H}_{2} \mathrm{O}$ $(0 \cdot 41)$ and $\left.\mathrm{NiCl}_{2} \cdot 6 \mathrm{H}_{2} \mathrm{O}(0 \cdot 13)\right]$, Tween $80\left(1 \cdot 0 \mathrm{ml} \mathrm{l}^{-1}\right)$ and agar $\left(20.0 \mathrm{~g} \mathrm{l}^{-1}\right)$. An AnaeroPack (Mitsubishi Gas) was used for creating anaerobic conditions and the incubation period was $72-120$ h at $37^{\circ} \mathrm{C}$. The strains were subcultured 
on Eggerth Gagnon (EG) agar (Merck) supplemented with $5 \%$ horse blood for 2 days at $37^{\circ} \mathrm{C}$ in an anaerobic jar (Hirayama) filled with $100 \% \mathrm{CO}_{2}$.

Amplification of the 16S rRNA gene of the studied strains was conducted using a PCR machine (Biometra). Universal primers $27 \mathrm{~F}\left(5^{\prime}\right.$-AGAGTTTGATCCTGGCTCAG- $\left.3^{\prime}\right)$ and 1492R (5'-GGTTACCTTGTTACGACTT-3') were used for the amplification of a fragment of approximately 1500 bases of the $16 \mathrm{~S}$ rRNA gene of the isolated strains. The amplified product was purified by using a Montage $\mathrm{PCR}_{96}$ filter plate (Millipore). A BigDye Terminator cycle sequencing kit (Applied Biosystems) and ABI PRISM 3100 Genetic Analyzer (Applied Biosystems) were used for sequencing, following the manufacturers' instructions. 16S rRNA gene sequences related closely to those of the isolated strains were retrieved from DDBJ, EMBL and GenBank. The sequences were aligned using CLUSTAL X (version 1.8) (Thompson et al., 1997). A phylogenetic tree was constructed based on the neighbour-joining method (Saitou \& Nei, 1987). Stability of the groupings was estimated by bootstrap analysis (1000 replications). Almost complete (1484-1488 bp) 16S rRNA gene sequences of the five strains were determined. 16S rRNA gene sequence similarity between strains $341^{\mathrm{T}}$ and 342 was $100 \%$. Phylogenetic analysis indicated that strains $341^{\mathrm{T}}$ and 342 were related most closely to Bacteroides uniformis $(94 \cdot 8 \%)$ and Bacteroides helcogenes $(92.0 \%)$ (Fig. 1). These low sequence similarities $(<97 \%)$ indicated that strains $341^{\mathrm{T}}$ and 342 represented a novel genomic species (Stackebrandt \& Goebel, 1994). The 16S rRNA gene sequence similarity between strain 344 and B. uniformis was $99 \cdot 6 \%$. Sequence similarity between strains 276 and 281 was $100 \%$ and the two strains showed $97.4 \%$ 16S rRNA gene sequence similarity to $B$. uniformis.

The API $20 \mathrm{~A}$ and API rapid ID 32 A systems (bioMérieux) were used for biochemical tests according to the manufacturer's instructions. Strains $341^{\mathrm{T}}$ and 342 produced the same biochemical reactions, except for the production of 6phospho- $\beta$-galactosidase (negative for strain $341^{\mathrm{T}}$ but positive for strain 342 ). Tests that are useful in distinguishing the novel taxon from some other Bacteroides species are summarized in Table 1 and results from the two API systems are listed in Supplementary Table S1 (available in IJSEM Online). Results of phenotypic analyses are listed in the species description below. Strain $341^{\mathrm{T}}$ demonstrated several differences from $B$. uniformis, including differences in acid production from salicin and L-rhamnose and production of 6-phospho- $\beta$-galactosidase. Biochemical characteristics of strain $341^{\mathrm{T}}$ that differed from those of $B$. helcogenes included indole production, acid production from salicin, L-arabinose and L-rhamnose and production of 6 -phospho- $\beta$-galactosidase, $\alpha$-arabinosidase, proline arylamidase, phenylalanine arylamidase and leucine arylamidase. The strains were grown on GAM (Nissui) agar plates supplemented with $2 \%$ Bacto oxgall (Difco) to test

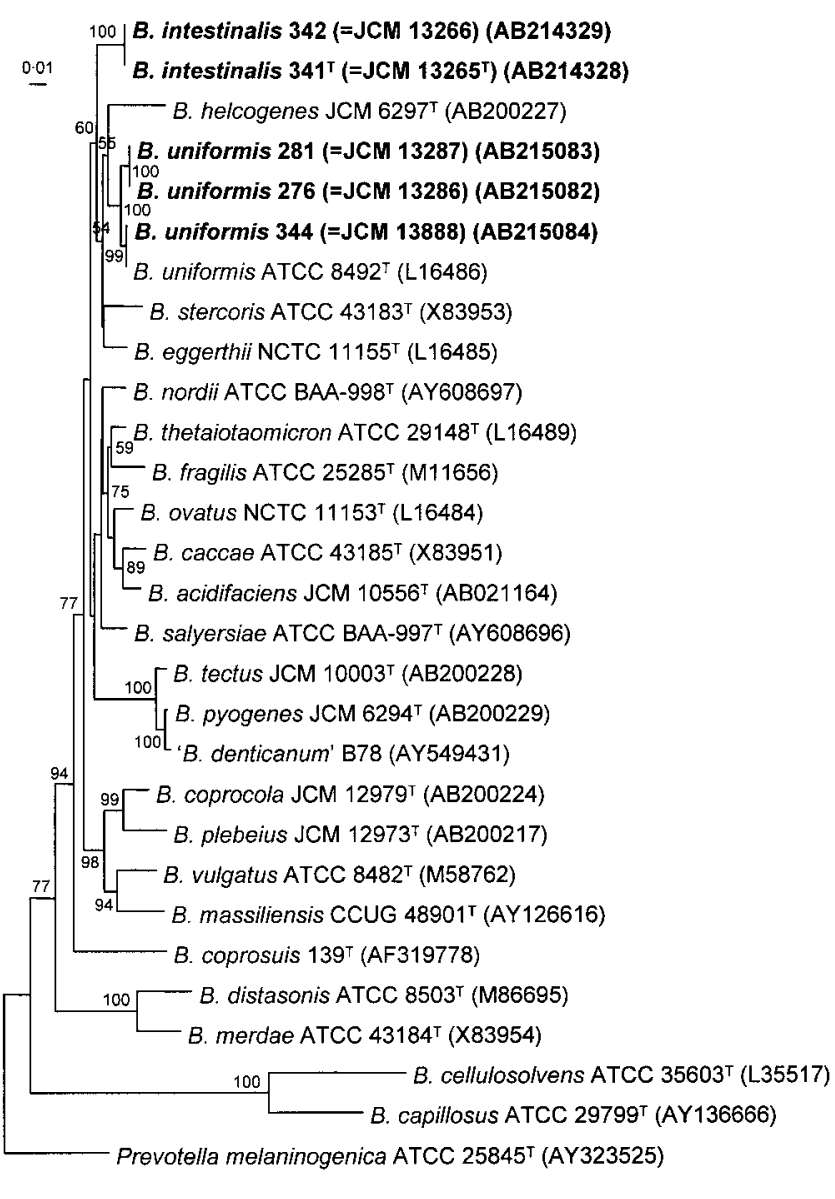

Fig. 1. Phylogenetic positions of the isolated strains in the genus Bacteroides. The tree was constructed by using the neighbour-joining method based on 16S rRNA gene sequences. Bootstrap values $>50 \%$ based on 1000 replications are listed as percentages at branching points. Bar, $1 \%$ sequence divergence.

for bile resistance. All the studied strains grew well in the presence of bile.

Cellular fatty acid compositions of the strains were determined following the method described by Sakamoto et al. (2002). The results are given in Supplementary Table S2. No significant differences were found in the fatty acid profiles of strains $341^{\mathrm{T}}$ and 342 . The major cellular fatty acid was anteiso- $\mathrm{C}_{15: 0}(32.0 \%)$, in agreement with data for the genus Bacteroides as described by Miyagawa et al. (1979). The closely related type strains of $B$. uniformis JCM $5828^{\mathrm{T}}$ and B. helcogenes JCM $6297^{\mathrm{T}}$ also contained anteiso- $\mathrm{C}_{15: 0}$ as the major cellular fatty acid ( $32 \cdot 5$ and $30.0 \%$, respectively).

Based on the results of physiological, biochemical, cellular fatty acid and phylogenetic analysis, two strains (276 and $341^{\mathrm{T}}$ ) were selected for determination of the $\mathrm{G}+\mathrm{C}$ content and for DNA-DNA hybridization experiments with reference strains B. uniformis JCM $5828^{\mathrm{T}}$ and B. helcogenes JCM $6297^{\mathrm{T}}$. For this purpose, bacterial cells were cultured in EGF 
Table 1. Biochemical characteristics that are useful in differentiating Bacteroides intestinalis sp. nov. from some members of the genus Bacteroides

Species: 1, B. intestinalis sp. nov.; 2, B. uniformis; 3, B. helcogenes (data in columns 1-3 from this study); 4, B. caccae (data from JousimiesSomer et al., 2003); 5, B. coprocola (Kitahara et al., 2005); 6, B. distasonis; 7, B. eggerthii; 8, B. fragilis (data in columns 6-8 from Jousimies-Somer et al., 2003); 9, B. massiliensis (Fenner et al., 2005); 10, B. merdae (Jousimies-Somer et al., 2003); 11, B. nordii (Song et al., 2004); 12, B. ovatus (Jousimies-Somer et al., 2003); 13, B. plebeius (Kitahara et al., 2005); 14, B. pyogenes (Benno et al., 1983); 15, B. salyersiae (Song et al., 2004); 16, B. stercoris; 17, B. thetaiotaomicron; 18, B. vulgatus (data in columns 16-18 from Jousimies-Somer et al., 2003). Characteristics are scored as: + , positive; - , negative; $\mathrm{V}$, variable; $+^{-}$, most strains positive; $-{ }^{+}$, most strains negative; ND, not determined.

\begin{tabular}{|c|c|c|c|c|c|c|c|c|c|c|c|c|c|c|c|c|c|c|}
\hline Characteristic & 1 & 2 & 3 & 4 & 5 & 6 & 7 & 8 & 9 & 10 & 11 & 12 & 13 & 14 & 15 & 16 & 17 & 18 \\
\hline Aesculin hydrolysis & + & + & + & + & + & + & + & + & + & + & + & + & + & $+^{-}$ & + & $+^{-}$ & + & $-{ }^{+}$ \\
\hline L-Arabinose & + & + & - & + & - & $-{ }^{+}$ & + & - & - & $-{ }^{+}$ & - & + & + & - & + & $-{ }^{+}$ & + & + \\
\hline D-Cellobiose & + & + & + & $+^{-}$ & + & + & $-^{+}$ & $+^{-}$ & - & $\mathrm{V}$ & + & + & + & $+^{-}$ & + & $-^{+}$ & $+^{-}$ & - \\
\hline L-Rhamnose & + & - & - & $+^{-}$ & + & $\mathrm{V}$ & $+^{-}$ & - & - & + & + & + & + & - & + & + & + & + \\
\hline Sucrose & + & + & + & + & + & + & - & + & + & + & + & + & + & $-^{+}$ & + & + & + & + \\
\hline D-Trehalose & - & - & - & + & - & + & - & - & - & + & - & + & - & - & - & - & + & - \\
\hline D-Xylose & + & + & + & + & + & + & + & + & - & + & + & + & + & - & + & + & + & + \\
\hline$\alpha$-Fucosidase activity & + & + & + & + & + & - & - & + & + & - & - & $+^{-}$ & + & $\mathrm{ND}$ & - & $\mathrm{v}$ & + & + \\
\hline
\end{tabular}

broth at $37^{\circ} \mathrm{C}$ for $12 \mathrm{~h}$ and then harvested. DNA was purified following the method of Saito \& Miura (1963). HPLC was used for determination of the DNA G+C content of the strains as described by Kitahara et al. (2001). The DNA G + C contents of strain $341^{\mathrm{T}}, B$. uniformis JCM $5828^{\mathrm{T}}$ and B. helcogenes JCM $6297^{\mathrm{T}}$ were 44,48 and $46 \mathrm{~mol} \%$, respectively (Supplementary Table S3). The $\mathrm{G}+\mathrm{C}$ content of strain $341^{\mathrm{T}}$ also supports its affiliation to the genus Bacteroides, members of which have $\mathrm{G}+\mathrm{C}$ contents of between 40 and 48 mol\% (Shah, 1992). The level of DNA-DNA hybridization was determined by the method of Ezaki et al. (1989). Strain $341^{\mathrm{T}}$ showed a level of DNADNA hybridization of $<9 \%$ with $B$. uniformis JCM $5828^{\mathrm{T}}$ and B. helcogenes JCM $6297^{\mathrm{T}}$ (Supplementary Table S3). The low DNA-DNA relatedness value $(<70 \%)$ with the most closely related Bacteroides species again indicated the novel species status of strain $341^{\mathrm{T}}$ (Stackebrandt \& Goebel, 1994). Strain 276 showed over 84 \% DNA-DNA relatedness with B. uniformis JCM $5828^{\mathrm{T}}$. $16 \mathrm{~S}$ rRNA gene sequence similarity between strains 276 and 281 was $100 \%$. Therefore, they were identified as representing $B$. uniformis.

On the basis of the results presented here, strain $341^{\mathrm{T}}$ should be classified as the type strain of a novel species of the genus Bacteroides, for which the name Bacteroides intestinalis sp. nov. is proposed.

\section{Description of Bacteroides intestinalis sp. nov.}

Bacteroides intestinalis (in.tes.ti.na'lis. N.L. masc. adj. intestinalis pertaining to the intestine).

Cells are strictly anaerobic, non-spore-forming, non-motile, Gram-negative rods, about $0 \cdot 8 \mu \mathrm{m}$ wide and $1-5 \mu \mathrm{m}$ long, and occur singly. Surface colonies on EG blood agar plates after 2 days are $1-3 \mathrm{~mm}$ in diameter, circular, translucent-whitish, raised and convex. The optimum temperature for growth is about $37^{\circ} \mathrm{C}$. Grows in the presence of bile. Indole-positive and able to hydrolyse aesculin. Nitrate is not reduced. No activity is detected for urease and gelatin is not hydrolysed. Acid is produced from glucose, lactose, sucrose, maltose, xylose, arabinose, cellobiose, mannose, raffinose and rhamnose. Acid is not produced from mannitol, salicin, glycerol, melezitose, sorbitol or trehalose. Positive reactions are obtained using API rapid ID $32 \mathrm{~A}$ for $\alpha$-galactosidase, $\beta$-galactosidase, $\alpha$ glucosidase, $\beta$-glucosidase, $\alpha$-arabinosidase, $N$-acetyl- $\beta$ glucosaminidase, glutamic acid decarboxylase, $\alpha$-fucosidase, alkaline phosphatase, leucyl glycine arylamidase, alanine arylamidase and glutamyl glutamic acid arylamidase. Mannose and raffinose are fermented. Negative reactions are obtained for arginine dihydrolase, $\beta$-glucuronidase, arginine arylamidase, proline arylamidase, phenylalanine arylamidase, leucine arylamidase, pyroglutamic acid arylamidase, tyrosine arylamidase, glycine arylamidase, histidine arylamidase and serine arylamidase. The result for 6phospho- $\beta$-galactosidase is variable. The major fatty acids are anteiso- $\mathrm{C}_{15: 0}(32 \cdot 0-33 \cdot 6 \%)$ and iso- $\mathrm{C}_{17: 0} 3-\mathrm{OH}$ $(18 \cdot 5-19 \cdot 2 \%)$. The DNA G $+\mathrm{C}$ content is $44 \mathrm{~mol} \%$.

The type strain, $341^{\mathrm{T}}\left(=\mathrm{JCM} 13265^{\mathrm{T}}=\mathrm{DSM} 17393^{\mathrm{T}}\right)$, was isolated from human faeces. Strain 342 (=JCM 13266) is included in this species.

\section{Acknowledgements}

We are grateful to Professor Hans G. Trüper, University of Bonn, Germany, for his suggestions regarding nomenclature and Dr Kuruto Hara, Kyodo Milk Industry Co. Ltd, Japan, for the preparation of polyamine-deficient medium. 


\section{References}

Bardocz, S., Grant, G., Brown, D. S., Ralph, A. \& Pusztai, A. (1993). Polyamines in food - implications for growth and health. J Nutr Biochem 4, 66-71.

Benno, Y., Watabe, J. \& Mitsuoka, T. (1983). Bacteroides pyogenes sp. nov., Bacteroides suis sp. nov., and Bacteroides helcogenes sp. nov., new species from abscesses and feces of pigs. Syst Appl Microbiol 4, 396-407.

Capano, G., Bloch, K. J., Carter, E. A., Dascoli, J. A., Schoenfeld, D. \& Harmatz, P. R. (1998). Polyamines in human and rat milk influence intestinal cell growth in vitro. J Pediatr Gastroenterol Nutr 27, 281-286.

Ezaki, T., Hashimoto, Y. \& Yabuuchi, E. (1989). Fluorometric deoxyribonucleic acid-deoxyribonucleic acid hybridization in microdilution wells as an alternative to membrane filter hybridisation in which radioisotopes are used to determine genetic relatedness among bacterial strains. Int J Syst Bacteriol 39, 224-229.

Fenner, L., Roux, V., Mallet, M. N. \& Raoult, D. (2005). Bacteroides massiliensis sp. nov., isolated from blood culture of a newborn. Int J Syst Evol Microbiol 55, 1335-1337.

Jousimies-Somer, H. R., Summanen, P. H., Wexler, H., Finegold, S. M., Gharbia, S. E. \& Shah, H. N. (2003). Bacteroides, Porphyromonas, Prevotella, Fusobacterium, and other anaerobic Gram-negative bacteria. In Manual of Clinical Microbiology, 8th edn, pp. 880-901. Edited by P. R. Murray, E. J. Baron, J. H. Jorgensen, M. A. Pfaller \& R. H. Yolken. Washington, DC: American Society for Microbiology.

Kitahara, M., Takamine, F., Imamura, T. \& Benno, Y. (2001). Clostridium hiranonis sp. nov., a human intestinal bacterium with bile acid $7 \alpha$-dehydroxylating activity. Int J Syst Evol Microbiol 51, 39-44.

Kitahara, M., Sakamoto, M., Ike, M., Sakata, S. \& Benno, Y. (2005). Bacteroides plebeius sp. nov. and Bacteroides coprocola sp. nov., isolated from human faeces. Int J Syst Evol Microbiol 55, 2143-2147.

McCormack, S. A., Blanner, P. M., Zimmerman, B. J., Ray, R., Poppleton, H. M., Patel, T. B. \& Johnson, L. R. (1998). Polyamine deficiency alters EGF receptor distribution and signaling effectiveness in IEC-6 cells. Am J Physiol 274, C192-C205.
Miyagawa, E., Azuma, R. \& Suto, T. (1979). Cellular fatty acid composition in Gram-negative obligately anaerobic rods. J Gen Appl Microbiol 25, 41-51.

Noack, J., Kleessen, B., Proll, J., Dongowski, G. \& Blaut, M. (1998), Dietary guar gum and pectin stimulate intestinal microbial polyamine synthesis in rats. J Nutr 128, 1385-1391.

Noack, J., Dongowski, G., Hartmann, L. \& Blaut, M. (2000). The human gut bacteria Bacteroides thetaiotaomicron and Fusobacterium varium produce putrescine and spermidine in cecum of pectin-fed gnotobiotic rats. J Nutr 130, 1225-1231.

Saito, H. \& Miura, K. (1963). Preparation of transforming deoxyribonucleic acid by phenol treatment. Biochim Biophys Acta 72, 619-629.

Saitou, N. \& Nei, M. (1987). The neighbor-joining method: a new method for reconstructing phylogenetic trees. Mol Biol Evol 4, 406-425.

Sakamoto, M., Suzuki, M., Umeda, M., Ishikawa, I. \& Benno, Y. (2002). Reclassification of Bacteroides forsythus (Tanner et al. 1986) as Tannerella forsythensis corrig., gen. nov., comb. nov. Int J Syst Evol Microbiol 52, 841-849.

Satink, H. P. W. M., Hessels, J., Kingma, A. W., van den Berg, G. A., Muskiet, F. A. J. \& Halie, M. R. (1989). Microbial influences on urinary polyamine excretion. Clin Chim Acta 179, 305-314

Shah, H. N. (1992). The genus Bacteroides and related taxa. In The Prokaryotes, 2nd edn, pp. 3593-3607. Edited by A. Balows, H. G. Trüper, M. Dworkin, W. Harder \& K. H. Schleifer. New York: Springer.

Song, Y. L., Liu, C. X., McTeague, M. \& Finegold, S. M. (2004), "Bacteroides nordii" sp. nov. and "Bacteroides salyersae" sp. nov. isolated from clinical specimens of human intestinal origin. J Clin Microbiol 42, 5565-5570.

Stackebrandt, E. \& Goebel, B. M. (1994). Taxonomic note: a place for DNA-DNA reassociation and 16S rRNA sequence analysis in the present species definition in bacteriology. Int J Syst Bacteriol 44, 846-849.

Thompson, J. D., Gibson, T. J., Plewniak, F., Jeanmougin, F. \& Higgins, D. G. (1997). The CLUSTAL_X Windows interface: flexible strategies for multiple sequence alignment aided by quality analysis tools. Nucleic Acids Res 25, 4876-4882. 